\title{
WHY WAS ASTROLOGY CRITICISED IN THE MIDDLE AGES? CONTRIBUTION TO FURTHER RESEARCH (ON THE BASIS OF SELECTED TREATIES OF PROFESSORS OF THE UNIVERSITY OF KRAKOW IN THE 15TH CENTURY)
}

People have always been interested in the firmament and in celestial alignments, wanting to read predictions of things to come in these mysterious, changing arrangements of heavenly bodies $^{\mathrm{I}}$. Movements and changes in the heavens were significant for humanity. Some people used a scientific approach, exploring secrets of the so-called academic astronomy, which was defined literally as the "law of the stars", whereas others practised practical astronomy, as astrology was usually referred to, defined also as the "speech of the stars".

Astrology was more than the study of the stars. It was intimately connected to people's ideas of themselves, their purpose and place in the universe. Astrology, often balancing on the border between science and magic, was often practised by representatives of almost all social classes and had its proponents even at the royal court (it often happened that kings or princes used the services of court astrologers ${ }^{3}$ ). However, its connotations with occult

S. J. Tester, A History of Western Astrology, London 1987; N. Campion, A History of Western Astrology, vol. 1, The Ancient and Classical Worlds, London 2008, vol. 2, The Medieval and Modern Worlds, London 2009; M. H. Malewicz, Zjawiska przyrodnicze w relacjach dziejopisarzy polskiego średniowiecza, Wrocław 1980, pp. $27-$ -48 , has devoted a lot of space to matters from the border area of astronomy and astrology in historiographic relations. See M. Markowski, Astronomica et astrologica Cracoviensia ante annum 1550, Firenze 1990, (Studi e Testi, t. 20); cf. S. Pagie, Astrology in Medieval Manuscripts, London 2002, etc.

A. Birkenmajer, Uniwersytet Krakowski jako międzynarodowy ośrodek studiów astronomicznych na przełomie XV i XVI stulecia, in: Odrodzenie w Polsce, vol. 2, Historia nauki, ed. B. Suchodolski, part 2, Warszawa 1956, p. 370. N. Campion, Introduction: Cultural Astronomy, (online) http://www.nickcampion.com/Portals/3/NicholasCampion, CulturalAstronomy.pdf, p. XXIII, considers that 'astrology might be reasonably classified as a species of "cultural astronomy" [acc. 15.04.2010].

3 For example, Władysław Jagiełło himself, together with his wife Zofia Holszańska, used the services of the astrologer Henricus Bohemus. See Joannis Dlugossii Annales seu cronicae incliti Regni Poloniae, liber undecimus: 1413-1430, Varsoviae 2000, s. 229. Joannis Dlugossii Senioris Canonici Cracoviensis Opera omnia, t. 13, Historiae Poloniae libri XII, t. 4, ed. A. Przezdziecki, Cracoviae 1877, s. 349-350; cf. B. Czwojdrak, Zofia Holszańska. Studium o dworze i roli królowej w późnośredniowiecznej Polsce, Warszawa 2012, pp. 127-128; A. Birkenmajer, Sprawa magistra Henryka Czecha, "Collectanea Theologica", 17, 1936, pp. 207-224. See also the Jagiellonian University Library, manuscripts 3225, 3227, (XV/XVI century) where we can find a lot of different horoscopes prepared for nobility. On that subject see E. Śnieżyńska-Stolot, "Zamek piękny na wzgórzu... ”. Horoskopy - zapomniane źródło historyczne, Kraków 2015, passim; M. Rożek, Magia, alchemia i ... królewskie horoskopy, Kraków 2016, pp.246-292. 
arts, perceived as sinful and heretical, resulted in a lot of allegations against astrology and astrologers, and beliefs about the celestial sphere were inextricably linked to the realm of religion or ideology $y^{4}$

Those accusations can be compiled into a specific catalogue of errores committed by defenders of this criticised study of the stars. What is important is the fact that the arguments against astrology were always the same. Opponents of astrology most often questioned the possibility of predicting future events on the basis of the arrangement of heavenly bodies, using astronomical instruments for seeking hidden treasure and using the help of the powers of darkness for this purpose, but most of all, the faith in astral, planetary or cometary determinism, which undermined the rudimentary Christian belief about the freedom of the human wills. The religious factor was the strongest element in determining whether astrology rose or fell in power, dignifying it as worthy of academic treatment, or denigrating it as a superstition.

The problem of the relationship between astrology and the Christian faith attracted some of the greatest minds of the medieval world, notably Saint Augustine, Roger Bacon, Albertus Magnus, Saint Thomas Aquinas, Pierre D’Ailly or Jean Gerson ${ }^{6}$. In the treaties of professors of the University of Krakow from the $15^{\text {th }}$ century one can also see a reflection of opinions expressed in the circles of opponents of astrology on this depreciated field of knowledge ${ }^{7}$. One of them, the long-serving rector of Krakow Alma Mater, Stanisław of Skarbimierz ${ }^{8}$ admitted that astrology could exist as a field of study dealing with the influence of celestial bodies.

4 T. O. Wedel, The Mediaeval Attitude Toward Astrology, Particularly in England, New Haven-London 1920, passim; J. Zathey, Z historii środowiska magiczno-astologicznego w Krakowie w XV wieku, "Krzysztofory. Zeszyty Naukowe Muzeum Historycznego Miasta Krakowa”, 8, 1981, pp. 7-21.

5 M. Markowski, Astrologia a wolna wola, “Alma Mater”, 2000, No. 20, p. 20; idem, Bóg a determinizm kosmiczny w polskich dziełach astrologicznych doby przedkopernikańskiej, "Studia Warmińskie”, 27, 1990, pp. 125-126; idem, Człowiek wobec wpływu ciał niebieskich $w$ okresie przedkopernikańskim, in: Człowiek i przyroda $w$ średniowieczu $i$ we wczesnym okresie nowożytnym, ed. Wojciech Iwańczak, Krzysztof Bracha, Warszawa 2000, pp. 115-116; idem, Der Standpunkt der Gelehrten des späten Mittelalters und der Renaissance dem astrologischen Determinismus gegenüber, "Studia Mediewistyczne", 23, 1984, 1, pp. 11-44; S. Konarska-Zimnicka, Astrologia Licita? Astrologia Illicita? The Perception of Astrology at Kraków University in the Fifteenth Century, "Culture and Cosmos. A Journal of the History of Astrology and Cultural Astronomy" 15, 2011, 2, pp. 65-86.

6 L. Thorndike, A History of Magic and Experimental Science, vol. 4, New York 1934, pp. 101-113, 114-131; see T. O. Wedel, Medieval Attitude Toward Astrology, pp. 64-65, 67-69; L. Ackerman-Smoller, History, Prophecy and the Stars. The Christian Astrology of Pierre d'Ailly, 1350-1420, Princeton-New Jersey 1994; see also P. Choisnard, Św. Tomasz z Akwinu i astrologia, Warszawa 1939, passim; J. D. North, Medieval Concept of Astrological Influence, in: Astrology, Science and Society. Historical Essays, ed. P. Curry, Woodbridge - Suffolk: Boydell 1987, pp. 5-17; M. Karas, Natura i struktura wszechświata w kosmologii św. Tomasza z Akwinu, Kraków 2007, passim; idem, Naturalne oddziaływanie ciał niebieskich na procesy zachodzace na ziemi w filozofii św. Tomasza z Akwinu, „Przegląd Tomistyczny", 15, 2009, pp. 45-75.

7 M. Markowski, Środowisko średniowiecznych przedstawicieli Uniwersytetu Krakowskiego wobec astrologii, 'Biuletyn Biblioteki Jagiellońskiej', 49, 1999, pp. 95-102; cf. Sylwia Konarska-Zimnicka, Mistrzów krakowskich z XV wieku kilka uwag na temat astrologii, 'Krzysztofory. Zeszyty Naukowe Muzeum Historycznego Miasta Krakowa', 25, 2007, pp. 39-50; A. A. Long, Astrology: arguments pro and contra, in: Science and Speculation. Studies in Hellenistic Theory and Practice, eds. Jonathan Barnes-Jacques Brunschwig-Myles Burnyeat-Malcolm Schofield, Cambridge 1982, pp. 165-192.

$8 \quad$ P. Trzebuchowski, Stanisław ze Skarbimierza, in: Filozofia w Polsce. Stownik pisarzy, Wrocław 1971, p. 364; S. Dobrzanowski, Stanisław ze Skarbimierza, in: Stownik polskich teologów katolickich, ed. Hieronim Wyczawski, vol. 4, Warszawa 1983, pp. 179-182; R. M. Zawadzki, Stanisław ze Skarbimierza (cc. 1365-1431), in: Polski Stownik Biograficzny, vol. 42, Warszawa-Kraków 2003, pp. 76-80; more details see L. Ehrlich, Paweł Włodkowic i Stanisław ze Skarbimierza, Warszawa 1964; cf. Bibliografia literatury polskiej. Nowy Korbut, vol. 3, Piśmiennictwo staropolskie, ed. R. Pollak, Warszawa 1965 (see further Nowy Korbut), pp. 234-236. 
However, he questioned the ability of astrologers to predict future events on the basis of the positioning of heavenly bodies, because he thought it was not possible to decide about chance events, which by their very nature do not possess, and even are unable to have, a particular reason. Stanisław of Skarbimierz explained: "For although it is permissible that a doctrine or science may be concerned with effects directly deriving from heavenly bodies, nevertheless the doctrine or science cannot be concerned with acts of free will, or chance events, or hidden buried treasure, since it is permissible that human acts can be influenced and also directed from the disposition of heavenly bodies as far as they derive from the sensitive soul, but not, as far as they derive from the intellective soul, because a human can, against

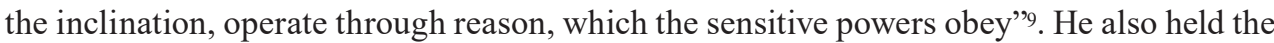
belief that the claim "Non posse resistere astrorum inclinationi" ("It is not possible to resist the inclination of the stars") is a long way from faith and even astronomical tradition, for already Ptolemy used to say, „Vir sapiens dominabitur astris” ("The wise man will rule the stars") ${ }^{10}$. Therefore, he questioned the influence of the astral world on the free will, which was one of the main arguments against astrology and its proponents. Jakub of Paradyż ${ }^{\text {II }}$, the author of the treatise De potestate daemonum, was of a similar opinion; he claimed that "heavenly bodies are not able to have an impact on free will directly by imprinting something, since intellect is not an act of an organic body" ${ }^{\prime 2}$. He admitted that heavenly bodies can incline a human body, but, in this situation, "a human may operate through reason"'s Thus, quoting Nicholas Campion, "any form of astrology which dealt with the natural world and the consequences of natural disorder or physical passion was permissible as long as it was clearly understood that moral choice was paramount"' ${ }^{\prime 4}$.

\footnotetext{
9 Stanisław of Skarbimierz: Consilia de Stanislai de Scarbimiria contre l'astroloque Henri Bohemus /Consilia Stanislai de Scarbimiria contra astrologum Henricum Bohemum. Edition critique/, ed. Stanisław Wielgus, "Studia Mediewistyczne", 25, 1988, 1, p. 159: "Nam licet possit esse doctrina vel scientia quo ad effectus immediate dependentes a corporibus coelestibus, non tamen potest esse doctrina vel scientia quo ad actus liberi arbitrii vel quo ad casus fortuitos vel occultos thesauros defossos, quoniam licet ex dispositione coelestium corporum possint inclinari actus humani et etiam dirigi quatenus dependent ab anima sensitiva, non sic tamen quatenus dependent $\mathrm{ab}$ anima intellectiva, quia contra inclinationem potest homo operari per rationem, cui obediunt vires sensitivae". See Aristotle, De anima, trans., introduction, notes by R. D. Hicks, Cambridge 1907, 414b30 et sqq, $415 \mathrm{a} 8$ et sqq, 415 b18 et sqq.

10 Ibidem, p. 160, 161, where we read: "Non posse resistere astrorum inclinationi - est a fide et etiam ab astronomicis traditionibus devius, eo quod ut ait Ptolemeus - Vir sapiens dominabitur astris". This saying is attributed to Ptolemy, though probably he is not the author. See Berthold von Regensubrg, Vollständige Ausgabe seiner Predigten, ed. F. Pfeiffer, Wien 1862, Bd. 1, p. 50.

11 K. Lepszy, Jakub z Paradyża (d. 1464), in: Polski Stownik Biograficzny, vol. 10, Wrocław-Warszawa-Kraków 1962-1964, pp. 363-364; S. Dobrzanowski, Jakub z Paradyża, in: Słownik polskich teologów katolickich, vol. 4, pp. 109-118; Nowy Korbut, vol. 3, pp. 85-87; see Jakub z Paradyża, Opuscula inedita, compiled by S. Porębski, Warszawa 1978, pp. 19-26; J. Stoś, Jakub z Paradyża-życie, działalność i pisma, "Studia Paradyskie", 3, 1993, pp. 129-140; cf. A. Porębski, Jakub z Paradyża. Poglady i teksty, Warszawa 1994.

12 Jakub of Paradyż, De potestate daemonum, Bayerische Staatsbibliothek in München, manuscript 18378, f. 265va: "Nec corpora celestia possunt agere in liberum arbitrium directe in primendo aliquod, cum intellectus non sit actus corporis organici"; see St. Augustine, O państwie Bożym. Przeciw poganom ksiag XXII, compiled by W. Kornatowski, vol. 1, Warszawa 1977, bk 5, ch. 1, p. 261. Cf. K. Bracha, Jakuba z Paradyża krytyka zabobonów, nadużyć i błędów w kulcie, in: Kartuzi. Teksty. Książki. Biblioteki, ed. S. Lorenz, E. Potkowski, Warszawa 1999, pp. 257-273.

13 Jakub of Paradyż, De potestate daemonum, f. 265va: “/.../ contra inclinationem corporum celestium homo possit per rationem operari”. See Aristotle, De anima, 406a5-406b28.

14 N. Campion, A History of Western Astrology, vol. 2, The Medieval and Modern Worlds, p. 50.
} 
This viewpoint was close to the opinion expressed by Stanisław of Zawada ${ }^{15}$, an academic lecturer and commentator on the Holy Scriptures, who negated the form of astrology which, within the systems of celestial spheres, seeks causes and predictions of future events which are dependent on the free will by their very nature, and which gives verdicts on the traits of a person being born on the basis of the signs of the $\operatorname{zodiac}^{16}$. This was in accordance not only with the Holy Scriptures (Isa. 47,9-IO and II-I4; Jer. 7, I8 and IO,2), but also with the letter of canon law, because Decretum Gratiani clearly criticised the attempts to force man's existence into the system of twelve signs of the zodiac and the so-called judicial astrology, which put the freedom of human will in doubt ${ }^{17}$. Jakub of Paradyż held a similar view; he desired to undermine the credibility of astrological forecasts, so he used the famous motif of twins, taken from Saint Augustine; twins are born under essentially the same astrological influences, nonetheless they lead very different lives $^{18}$. It is obvious that the most basic use of astrology was to prepare horoscopes which would indicate the influence the stars, planets or comets had on a person at the birth time (the recipients of the horoscopes were most often wealthy people, especially kings, princes and even bishops and popes!). Knowing where the celestial bodies were located at the birth time, an astrologer could predict their influence on the person's character, decisions and general destiny ${ }^{19}$. The faith

15 S. Dobrzanowski, Stanisław z Zawady, in: Słownik polskich teologów katolickich, vol. 4, pp. 182-183; M. Szafariewicz, Stanisław z Zawady. Rys biograficzny, “Acta Mediaevalia”, 4, 1983, pp. 83-97; M. Zwiercan, Stanisław z Zawady (d. 1491), in: Polski Słownik Biograficzny, vol. 42, pp. 96-97; M. Szafarkiewicz, Edycja wybranych kwestii komentarza do Księgi Rodzaju (cz. 1) Stanisława z Zawady, "Acta Mediaevalia”, 3, 1978, pp. 109-143; S. Wielgus, XV-wieczny komentarz Stanisława z Zawady do Księgi Rodzaju, "Acta Mediaevalia”, 2, 1974, pp. 121-189; M. Szafarkiewicz, Czwarty dzień stworzenia wedtug Komentarzy do Księgi Rodzaju Stanisława z Zawady i Henryka z Hesji, “Acta Mediaevalia”, 5, 1989, pp. 143-249.

16 M. Szafarkiewicz, Uwagi dotyczace edycji krytycznej wybranych kwestii z Komentarza do Księgi Rodzaju cz. I, rkps. BJ 1358, kk.136v-141v Stanisława z Zawady, “Acta Mediaevalia”, 2, 1974, pp. 307-308, where we read: “[...] Astrologia autem est, quae astrorum et partium coeli conditiones et habitudines observant et eas considerat tamquam causas vel signa effectuum futurorum in hoc mundo inferiori. [...] Superstitiosa vero est in hiis eventibus, qui libero arbitrio subiacent quam mathematici sequuntur, qui in stellas augurantur, quique etiam 12 signa per singula animae vel corporis membra disponunt, siderumque cursus nativitates hominum et mores praedicare noscuntur'. We can see here the clear influence of Isidore of Seville, Etymologiarum sive originum libri XX, ed. W. M. Lindsay, vol. 1, Libros I-X continens, Oxonii 1911 (Scriptorum Clasicorum Bibliotheca Oxoniensis), III.24-28; and Hugh of Saint Victor, Opera omnia, in: Patrologiae Cursus Completus. Series Secunda, accurante J. P. Migne, vol. 177, Parisiis 1854, col. 199: Exerptionum allergoricarum libri 24, Pars I, Excerptionum priorum liber primus, c. 12, De astronomia et astrologia; cf. S. Konarska-Zimnicka, Astrologia Licita?, pp.74-75.

17 Decretum Gratiani, Pars II, C. XXVI, c. 1, qu. 2-4, in: Corpus Iuris Canonici, ed. E. Friedberg, Graz 1955, vol. 1, col. 1025-1026; ibidem, Pars I, D. XXXVII, c. 7, in: Corpus Iuris Canonici, vol. 1, col. 135; ibidem, Pars II, c. XXVI, qu. 2, c. 9, in: Corpus Iuris Canonici, vol. 1, col. 1023. See also M. Szafarkiewicz, Uwagi, pp. 309-311; M. H. Malewicz, „Pochwała astrologii” Jana z Głogowa, czyli historia sporu astrologów z teologami, “Wiedza i Życie”, 1990, 4, p. 38.

18 Jakub of Paradyż, De potestate daemonorum, f. 266va, where we read: "Certe cum Jacob de utero egredevetur [sic!] et prioris fratris plantam teneret manu prior perfecte nequaquam egredi potuit, nisi et subsequens indicasset et tamen cum uno eodemque momento utrumque mater fuderit, non una utrusque vite qualitas fiunt. Sed ad hoc solent mathematici respondere, quia virtus constellationis in ictu pungentis est”; see St. Augustine, O państwie, bk 5, ch. 4, p. 264; idem, De doctrina christiana, ed. J. Sulowski, Warszawa 1989, pp. 85-87. Astrologers were also called "mathematici". See. A. Woziński, W świetle gwiazd. Sztuka i astrologia w Gdańsku w latach 1450-1550, Gdańsk 2011, pp. 23-42.

19 R. Kieckhefer, Magic in the Middle Ages, Cambridge 2000, pp. 120-123; see. J. D. North, Horoscopes and History, London 1986, passim; J. H. Holden, A History of Horoscopic Astrology. From the Babylonian Period to the Modern Age, Arizona 2006, passim; E. Śnieżyńska-Stolot, Horoskopy dziecka królowej Jadwigi, „Biuletyn Biblioteki Jagiellońskiej” 53, 2003, pp. 5-32; eadem, Horoskop Kazimierza Jagiellończyka - nowe źródto do treści ideowych wawelskiego nagrobka króla, „Biuletyn Biblioteki Jagiellońskiej” 60, 2010, pp. 5-30; eadem, Generale iudicium Władysława II zwanego Warnénczykiem, "Biuletyn Biblioteki Jagiellońskiej” 61, 2011, pp. 13-41; eadem, Almanach pro reverendissimo domino cardinali Fryderyka Jagiellończyka - historyczne źródło warsztatu astrolo$g a$, ,Biuletyn Biblioteki Jagiellońskiej” 63, 2013, pp. 5-70. 
in natal horoscopes in the Middle Ages was regarded as standing in opposition to the Christian religion. Benedict Hesse - the rector of the Cracow University - also opposed the claim that man's fate was predetermined from the moment he entered into the world ${ }^{20}$. In his opinion, beginning from the moment of birth, every man had the right to exercise free will, although he admitted that the human body could be subjected to the influence of heavenly bodies. He did not believe, however, in complete cosmic determinism, considering that man would always have the possibility of choice, and, therefore, would remain in control of his deeds ${ }^{21}$. This topic was also taken up by Tomasz of Strzempin ${ }^{22}$, doctor of canon law, who claimed that "For intellect or reason is neither a body nor the act of a bodily organ, and consequently nor is the will, which is in the reasoning power[...] Therefore no body can make an imprint on something incorporeal. Whence it is impossible for heavenly bodies to make an imprint directly on the intellect and will'" ${ }^{23}$. As a consequence, free will was completely outside the range of the cosmic influence. Therefore, all astrological forecasts should be considered as superstitious and prohibited. Moreover, Jakub of Paradyż, who was quoted before, emphasised that astrologers publicly announced only universal and widely-held truths, which they could be sure would be fulfilled, but as "the mass of fools confidently believing in astrological prophecies is infinitely great", these prophecies enjoyed unfaltering popularity ${ }^{24}$. However, one should notice that Jakub of Paradyż did not negate those astrological practices based on detailed observations of the heaven which aimed to predict natural phenomena, because in such a form they did not undermine the dogmas of the Christian faith and did not contravene the teachings of the Church ${ }^{25}$. In such cases, he even

20 Benedictus Hesse, Lectura super Evangelium Matthaei, ed. W. Bucichowski, Warszawa 1982, p. 40, where we read: "Ideo simpliciter est negandum, quod homo in hora suae nativitatis sit fatatus, sed secundum quod bona vel mala facerit vel gesserit, etiam bona vel mala potest recipere et operari"; see M. Rechowicz, Hesse Benedykt (d. 1456), in: Polski Stownik Biograficzny, vol. 9, Wrocław-Warszawa-Kraków 1960-1961, pp. 485-486.

21 Benedictus Hesse, Lectura, p. 40, where we read: "Ideo nunquam ex impressione caelestium corporum nostra corpora sic disponuntur ad aliquod bonum prosequendum, quoniam possumus agere contrarium nec unquam sic inclinatur ad operandum aliquod malum, quoniam per liberum arbitrium et per habitum virtutis possumus contra talem inclinationem et dispensationem agere, quia domini sumus per voluntatem a principio usque ad finem omnium actuum nostrorum secundum Philosophum tertio Ethicorum".

22 M. Markowski, Dzieje Wydziału Teologii Uniwersytetu krakowskiego w latach 1397-1525, Kraków 1996 , pp. 149-151; S. Dobrzanowski, Strzempiński Tomasz, in: Słownik polskich teologów katolickich, vol. 4, pp. 221-223; cf. Z. Włodek, Z badań nad filozofia człowieka w późnośredniowiecznej eschatologii krakowskiej. Poglady Tomasza ze Strzempina, "Studia Mediewistyczne”, 29, 1992, pp. 159-169; cf. T. Wojciechowski, Tomasz Strzempiński (1398-1460), Warszawa 1975.

23 The Jagiellonian University Library, manuscript 2070, f. 175r, 176r, where we read: 'Intellectus enim sive racio non est corpus neque actus organi corporei et per consequens nec voluntas, que est in racione [...]. Nullum autem corpus potest imprimere in rem incorpoream. Unde impossibile est, quod corporea celesita directe imprimant in intellectum et voluntatem". Compare Thomas Aquinas, Summa Theologiae, 2-2, Q. 95, art. 5.

24 Jakub of Paradyż, De potestate daemonum, ff. 265vb-266ra, where we read: "Pauci autem sunt, scilicet soli sapientes, qui per racionem huiusmodi inclinationes moderantur, ideo vera pronunciat astrologi maxime in communibus eventibus, quia dependent ex multine, quia stultorum infinitus est numerus pronerbionum. [...] Quia dicunt astrologi, quod sapiens homo dominabitur astris. In quantum domintur suis passionibus". Compare The Jagiellonian University Library, manuscript 2070, f. 176r, where we read: “[...] pauci autem sunt, i.e. solum sapientes, qui ratione huiusmodi inclinaciones moderentur, et ideo astrologi in multis vera prenunciant et precipue in communibus evenbus, qui dependent ex multitudine".

25 Jakub of Paradyż knew ways of forecasting changes in the weather based on animal observation, e.g. the sweating of a donkey's ears or changes on a dog's body. See Jakub of Paradyż, De potestate daemonum, f. 265vb, where we read: "Sicut etiam in aliis rebus in quibus influunt corpora celestia. Ut in sudatione aurium astinorum et [...] in corporum canum, praecognoscuntur pluvie”. See Thomas Aquinas, Summa Theologiae, 2-2, Q. 94, art. 3, 7. 
allowed for the possibility of mistakes resulting from the multiplicity and unpredictability of the causes appearing within the natural environment ${ }^{26}$.

Such partial approval is also visible in the works of Stanisław of Zawada. In his Commentary to the Book of Genesis, the most interesting is the commentary to the fourth day when the heavenly firmament was created. The author concentrated on the necessity and purpose of creating luminous bodies, which were mainly meant to be beautiful and practical ${ }^{27}$. Therefore, one may conclude that his approval referred not to astrology, but, above all, to astronomy. It seems that the philosophical debate on astrology distinguishes the belief in real planetary influences, which themselves may be conceived as either physical or metaphysical in nature, from the astrology of "signs" and "omens" in which a divine force communicates with humanity via the $\operatorname{stars}^{28}$. Without a doubt, certain basic applications of astrology were noncontroversial. Its influence on the human body and on climate was generally accepted, and thus there was little objection to its use in healing or in predicting weather ${ }^{29}$.

Astrologers tried to explore the mysteries of heaven by using various astronomical instruments, such as the torquetum or the astrolabe ${ }^{30}$. Tomasz of Strzempin approved the use of these instruments to research the heavenly firmament, but opposed the use of the knowledge thus obtained to forecast those future events which were the result of well-thought out human decisions ${ }^{31}$. Unfortunately, as one may deduce from reading the sources, astrologers eagerly used these instruments for prophetic purposes, even though the provisions of canon law forbade it, warning that "qui videt per astrolabium duobus annis peniteat" ${ }^{2}$. Stanisław of Skarbimierz was also definitely against it, claiming that the use of astrological knowledge

26 Jakub of Pararadyż quoted Thomas of Aquinas's Summa Theologiae (2-2, Q. 94, art. 5), and claimed that the prediction of future events on the basis of the position of the stars and planets could be permitted only when it referred to natural phenomena. Jakub of Paradyż, De potestate daemonum, ff. 265va-265vb, where we read: 'Prognosticatio futurorum effectuum per astra, stellas et planetarum cursum seu motus celestium corporum aliquando est licita, aliquando illicita. [...] Hec praepositio probatur in hiis effectibus, qui de necessitate ex causis istorum eveniunt, ut per astronomos eclipses praenoscuntur, licita enim. (...) Si vero utat quos ex consideratione astrorum ad praecognoscundum futura, que ex celestibus causantur scilicet siccitates, plumvias non erit illicitum, licet sepius fallit propter aliquas occurentes causes'; see P. Choisnard, Św. Tomasz z Akwinu i astrologia, p. 42; cf. M. Zembrzuski, List o korzystaniu z wyroków gwiazd (De iudiciis astrorum) św. Tomasza z Akwinu, in: Opera Philosophorum Medii Aevi Textus et Studia, vol. 9, fasc. 1: Tomasz z Akwinu - Opuscula, ed. A. Andrzejuk, M. Zembrzuski, Warszawa 2011, pp. 79-81; idem, Czy wedtug Tomasza z Akwinu można korzystać z wyroków gwiazd?, in: Przyrodoznawstwo-Filozofia-Teologia - obszary i perspektywy dialogu, ed. J. Meller, A. Świeżyński, Warszawa 2010, pp. 29-46.

27 M. Szafarkiewicz, Edycja, p. 113; ibidem, p. 120, where we read: "Secundo serviunt hominibus inquantum ex eis sumi possunt iudicia quaedam de propinquo futuro qualitatis aeris. Et quantum ad hoc dicit littera: „Et sint in signa" scilicet eventuum naturalium scilicet pluviae siccitatis, caloris et frigoris. Necessarius (...) vitae humane sicut longior usus docet, signorum notationes et observationes invenies, si tamen non amplius eas quam oportet inquiras. Multa enim super futuris imbrimus possumus dicere; plurima quoque vaporibus terrarum, motibusque ventorum, seu per partes vehementium, seu generaliter ubisque spirantium, et utrum violenter, an placide sint venturi”.

28 N. Campion, Astrology, p. 1, (online) http://www.nickcampion.com./Portals/3/Text03.pdf [acc. 10.04.2014].

29 S. Jenks, Astrometeorology in the Middle Ages, „Isis” 74, 1983, 2, s. 185-210; R. Kieckhefer, Magic in the Middle Ages, p. 127; R. Klibansky, E. Panofsky, F. Saxl, Saturn i melancholia. Studia z historii, filozofii, przyrody, medycyny, religii oraz sztuki, transl. A. Kryczyńska, Kraków 2009, passim.

30 See G. Rosińska, Instrumenty astronomiczne na Uniwersytecie Krakowskim, Wrocław 1974 (Studia Copernicana, 9); eadem, Mikołaj Kopernik i tradycje krakowskiej szkoły astronomicznej. Znajomość traktatów o instrumentach astronomicznych $w$ Krakowie $w X V$ w., "Studia Warmińskie", 9, 1972, pp. 339-401.

31 The Jagiellonian University Library, manuscript 2070, f. 175r, where we read: 'Si autem fiat iudicium de hiis, que subsunt libero arbitrio, que non sunt subiectu legi astrorum, peccatum est in hiis magnam fidem adhibere'.

32 Decretum Gratiani, Pars II, c. 1, D. XXVI, qu. 5, c. 3, in: Corpus Iuris Canonici, vol. 2, col. 1027; see J. Sawicki, Consilia Poloniae. Studia i źródła krytyczne, vol. 10, Synody diecezji wrocławskiej i ich statuty, Wrocław- 
and astronomical instruments for the satisfaction of human curiosity or even for utilitarian aims "est erroneus et de fide suspectus" 33 . He also claimed that "whoever seeks help from the enemies of God gives up on God's help, esteeming God's enemies as stronger than God; therefore to invoke demons for help in finding buried treasure is heretical" 34 .

Moreover, while examining the writings of authors participating in the discussion about astrology, one may notice that astrologers, for example Henricus Bohemus and supporters of astrology, were accused of owning forbidden magic books, including the famous Grimo Ire or Picatrix, which contained spells to summon demons ${ }^{35}$, and of supporting Hussitism, the movement perceived as heretical, which was contrary to the teachings propagated by the $\mathrm{Church}^{36}$.

While such eminent figures of science and the Church of the day as Stanisław of Skarbimierz, Stanisław of Zawada, Jakub of Paradyż, Tomasz of Strzempin and Benedict Hesse distanced themselves from astrology and questioned the reliability of astrological prognostications, Jan of Głogów wrote the treaty Persuasio brevis quomodo astrologiae studium religioni christianae non est adversum in which he attempted to defend astrology ${ }^{37}$. He invoked the same claims as the opponents of astrology did, including the famous "Sapiens dominabitur astris" ${ }^{38}$, which in his opinion proved that knowledge deriving from the study of the stars should not be excessively feared, for a thinking man is able to limit the influence of celestial bodies. Yet he made a reservation that one needs to be aware of their force and deal with them skilfully, not ignoring God, who is their Creator ${ }^{39}$. He asked those who were against astrology not to fight insidiously against something that they do not really know, because 'astrologia religioni christianae non est adversum' 40 .

Warszawa-Kraków 1963, p. 382; see Statuta synodalia Wenceslai episcopi wratislaviensis, in: Statuta synodalia dioecesana sanctae ecclesiae wratislaviensis, ed. M. de Montbach, Wratislaviae 1855, p. 36.

33 Stanisław of Skarbimierz: Consilia, p. 159, 160, where we read: "Igitur dicere, quod licitum sit per astrolabium invenire occultos thesauros, in terra defossos, est dicere contra determinationem ecclesiae et per consequens haereticum".

34 Stanisław of Skarbimierz: Consilia, pp. 158, where we read: "Qui petit auxilium ab inimicis Dei, de auxilio Dei desperat, validores sibi existimans inimicos Dei quam Deum; igitur invocare daemones pro auxilio ad inveniendum thesauros defossos, est haereticum'; compare Extravagantes Communis, Lib. V, Tit. VIII, De poenis, c. 1, in: Corpus Iuris Canonici, vol. 2., col. 1302-1303; ibidem, Lib. V, Tit. X, De sententia excommunicationis, c. 1-4, col. 1309-1312; see Thomas Aquinas, Summa Theologiae, 2-2, Q. 95, art.5.

35 Picatrix. The Latin Version of the Ghāyat al-hakim, ed. D. Pingree, London 1986; see V. Perrone Compagni, 'Picatrix'latinus. Concezioni filosofico-religiose e prassi magica, "Medioevo. Rivista di storia della filosofia medievali", 1, 1975, pp. 237-277. See L. Thorndike, A History of Magic, vol. 4, pp. 242-243. K. Thomas, Religion and the Decline of Magic, Middlesex 1971, p. 757, noted that astrology and witchcraft are essentially rival explanatory models. See. L. S. de Camp, C.C. de Camp, Duchy, gwiazdy i czary, trans. W. Niepokólczycki, Warszawa 1970, pp. 424-449; cf. J. B. Russell, Witchcraft in the Middle Ages, New York 1972, p. 115; E. Garin, Rozważania na temat magii, "Odrodzenie i Reformacja w Polsce", 15, 1970, pp. 7-21.

36 Henricus was referred to as "de Brega", i.e. of Brzeg in Silesia or "de Praga", hence from Prague. Yet he appears in the inquisitional acts as "Bohemus". A. Birkenmajer, Henryk Czech (d. after 1428), in: Polski Stownik Biograficzny, vol. 9, Kraków 1960, pp. 419-420; cf. J. Kuchta, Nauki tajemne w Polsce w XV i XVI wieku, "Lud”, 27, 1928, 7, p. 79.

37 Jan of Głogów, Persuasio brevis quomodo astrologiae studium religioni christianae non est adversum, ed. M. H. Malewicz, “Studia Mediewistyczne”, 24, 1985, No. 1, pp. 153-175.

38 Ibidem, pp. 174-175.

39 Ibidem, p. 175, where we read: "Certe hoc hic reprobatur illi qui virtuti stellarum inesse credunt utilitatem et qui colunt stellas et planetas sicut Deus".

40 Ibidem, p. 175, where we read: "Iam satis et sufficienter verae astrologiae studium defensum creditur et fidei Christianae non adversum, quin immo viris katholicis utile et accommodum. Valeant ergo artis astrorum obtrectatores idque, quod ignorant, minime velint impugnare". 
Undoubtedly, this ambivalence resulted from the unusual popularity of astrology among all social classes and the fact that it flourished beyond the university walls, which forced theologians and professors not only to revise their views, but first and foremost to mitigate accusations addressed towards astrologers and their supporters. And even though there were still opponents of astrological determinism, the majority of scholars agreed that heavenly bodies were exerting influence on earthly matters, but they disputed the scope and the size of the influence ${ }^{4 \mathrm{I}}$.

\section{Why was astrology criticised in the Middle Ages? \\ Contribution to further research (on the basis of selected treaties of professors of the University of Krakow in the 15th century) Summary}

People have always been interested in distant, mysterious celestial bodies. Astrologers who explored the mysteries of the study of the stars and planets wanted to read them as predictions of future events. Astrological practices were often seen as bordering of magic, which to a large extent influenced the negative perception of this area of study and its supporters, even though astrologers were employed at the kings' and bishops' courts, and even at the papal court. The relationship of astrology with occult sciences, which were regarded as sinful and heretical, led to the situation when its proponents were subject to accusations. Particular attention was paid to the fact that the belief in the influence of heavenly bodies on the events taking place in the sublunary world undermines the foundation of the Christian religion, i.e. the dogma of the free will of man. This and other charges constituted a kind of a "catalogue of allegations" that were made against astrology and astrologers throughout the Middle Ages.

Keywords: astrology, cosmic determinism, critique of astrology, Christian religion, Krakow University

\section{Dlaczego w średniowieczu krytykowano astrologię? Przyczynek do dalszych badań (w oparciu o wybrane traktaty profesorów Uniwersytetu Krakowskiego z XV wieku) Abstrakt}

Zainteresowanie ciałami niebieskimi nieustannie towarzyszyło człowiekowi. Astrologowie, zgłębiający tajniki nauki o gwiazdach i planetach, pragnęli wyczytać z nich zapowiedź mających nadejść wydarzeń. Praktyki astrologiczne często postrzegano jako balansujące na granicy magii, co w znacznej mierze wpływało na negatywne postrzeganie tej nauki i jej zwolenników, pomimo tego, iż zarówno na dworach królewskich, czy biskupich, a nawet na dworze papieskim zatrudniano astrologów. Konotacje astrologii z uważanymi za grzeszne i heretyckie naukami tajemnymi sprawiały, że jej zwolennikom stawiano zarzuty, pośród

\footnotetext{
${ }^{41}$ Undoubtedly it was an announcement of coming changes, the more so as Marcin Król of Żurawica, considered to be the "father" of the astronomic school, in 1453 founded at te university in Kraków a special department of astrology. R. Bugaj, Nauki tajemne w Polsce w dobie Odrodzenia, Wrocław-Warszawa-Kraków-Gdańsk 1976, p. 100; cf. A. Birkenmajer, Uniwersytet Krakowski jako międzynarodowy ośrodek, p. 364, footnote 2; see M. Markowski: Powstanie petnej szkoty astronomicznej w Krakowie, in: J. Dobrzycki, M. Markowski, T. Przypkowski, Historia astronomii $w$ Polsce, vol. 1, ed. E. Rybka, Wrocław-Warszawa-Kraków-Gdańsk 1975, p. 89; cf. L. S. de Camp, C.C. de Camp, Duchy, gwiazdy i czary, s. 44.
} 
których szczególną uwagę zwracano na fakt, iż wiara w oddziaływanie ciał niebieskich na wydarzenia rozgrywające się w świecie podksiężycowym godzi w fundament religii chrześcijańskiej, tj. dogmat o wolnej woli człowieka. Ten i inne zarzuty ułożyły się w swoisty "katalog zarzutów", które wysuwano pod adresem astrologii i astrologów przez cały okres wieków średnich.

Słowa kluczowe: astrologia, determinizm kosmiczny, krytyka astrologii, religia chrześcijańska, Uniwersytet Krakowski

Nota o Autorze: pracownik Instytutu Historii Uniwersytetu Jana Kochanowskiego w Kielcach (Zakład Historii Średniowiecznej). Zainteresowania badawcze: historia średniowieczna i wczesnonowożytna (kultura, życie codzienne, nauka: medycyna, ziołolecznictwo, astronomia, astrologia, filozofia przyrody), edytorstwo źródeł, socjologia. 